\title{
State-of-the-art of the historical seismology in Colombia
}

\author{
Armando Espinosa Baquero $\left({ }^{1}\right)$, Augusto Antonio Gómez Capera $\left({ }^{2}\right)$ \\ and Elkin de Jesús Salcedo Hurtado $\left(^{3}\right)$ \\ (1) Facultad de Ingeniería, Universidad del Quindío, Armenia, Colombia \\ ${ }^{(2)}$ Istituto Nazionale di Geofisica e Vulcanologia, Sezione di Milano, Italy \\ (3) Departamento de Geografía, Universidad del Valle, Cali, Colombia
}

\begin{abstract}
In Colombia are available a discreet number of historical seismology investigations, dating back 50 years. This paper reviews basic information about earthquakes studies in Colombia, such as primary sources, compilation of descriptive catalogues and parametric catalogues. Father Jesús Emilio Ramírez made the main systematic study before 1975. During the last 20 years, great earthquakes hit Colombia and, as consequence, historical seismology investigation was developed in the frame of seismic hazard projects.
\end{abstract}

Key words earthquakes - historical seismology catalogue - intensity - Colombia

\section{Introduction}

The Colombian territory located in the northwestern corner of South America, is the place of convergence of three lithospheric plates: Nazca, Caribbean and South American. The movement of these plates produces large deformation zones characterized by the presence of different types of geologic faults (Paris et al., 2000). The region surrounding these faults has produced several destructive earthquakes in the past centuries. The most significant earthquake in casualties and financial loss occurred on 20 January 1999 in the coffee growing region (Armenia earthquake), with magnitude 6.2 and $I_{\max }=\mathrm{X}$ MM 56; it killed

Mailing address: Dr. Armando Espinosa Baquero, Facultad de Ingenieria, Universidad del Quindío, Avenida Bolívar Calle 12 Norte Edificio de Ingeniería, Quindío, Armenia, Colombia; e-mail: armandoespinosa@uniquindio.edu.co
1230 people and destroyed more of 5600 homes, the economic impact of this earthquake symbolizes a direct economic loss of approximately US\$ 1.8 billion (Cardona, 1999).

Most of the studies carried out for Colombian strong earthquakes give information only on epicentral coordinates and magnitude. Moreover, incomplete reports of building damage in the main affected cities conclude sometimes in a layout of incomplete isoseismal maps. Also, it cannot be assumed that all the earthquakes with intensity $\left(I_{0} \geq\right.$ VII $)$ that have happened in Colombia are included in the existent seismic catalogues.

The first scientific effort to map the earthquakes with epicentres in Colombian territory was carried out by the geographer Francisco Javier Vergara y Velasco (Vergara y Velasco, 1906a; Vergara y Velasco, 1906b), who published the first seismological map of the country and wrote some notes on its historical seismicity (Vergara y Velasco, 1898). Another important contribution to the seismic history of the country are the studies carried out by the Jesuit priest Simón Sarasola (1924, 1937). Many investigators consider him the father of seis- 
mology in Colombia, because in 1923 he installed the first three seismographs in Colombia, and in 1941 participated in the creation of the Geophysical Institute of the Andes, which included also a meteorological observatory.

The first systematic work on historical seismicity in Colombia from the 16th century, is History of the Earthquakes in Colombia by the Jesuit priest Jesús Emilio Ramírez, published for the first time in 1969 and reissued in the year 1975. The main seismic catalogues for the Colombian territory are those by Ramírez (1975a), CERESIS (1985), ITEC (1988), and INGEOMINAS $(1993,2002)$. Most of these catalogues are based on Ramirez's work.

Recent contributions to the knowledge of the seismic history of Colombia have been made by Espinosa who has also partially revised the seismic catalogues. New seismic events, previously ignored (Espinosa, 1994b-d), have been included in the catalogues and at the same time some doubtful seismic events were discarded, after being recognized as other type of natural events (Espinosa, 1994e-f).

\section{Historical background}

\subsection{Early compilations}

During the first century of Spanish colonial times, only special chroniclers and curious persons dedicated their time to narrate what occurred in the towns seriously affected by earthquakes. Early compilations of Colombian historical earthquakes are found in personal notes and autobiographies, containing information on earthquake records in different time periods, made by some foreign scientists and a few nationals, with sufficient education and interest in science and history, who dedicated themselves to recording and describing the earthquakes felt in their own localities. Such compilations, which have a local character and are only partial, can nevertheless be considered as the first seismic catalogues of Colombia, among which are the documents of Luis Vargas Jurado (edited by Caballero in 1902), the list of Don Santiago Pérez de Valencia (edited by Acosta in 1849 as quoted by Espinosa, 1997) for Popayán, since 1800 through 1841, that of
Don José María Caballero (1902), from 1813 to 1819. In the middle of the century there were historical sources as Boussingault (1829, 1833, 1835), Acosta (1828) and international scientists such as Montessus de Ballore (1884) and others, who collected and catalogued seismic data. These authors are mentioned by Ramírez (1975a), CERESIS (1985) and Espinosa (1997, 2004).

Luis Vargas Jurado was an employee of the «Nueva Granada» viceroyalty, who wrote a diary in Santa Fe de Bogota, which is the oldest document with information on natural phenomena and their consequences in Colombia from 1703 to 1780. This work was published in 1902 by José María Caballero. The main earthquake quoted by Vargas Jurado occurred on 18 October 1743 and was felt in Bogota, surrounding areas and the eastern Colombian region (Vargas Jurado, 1902).

Santiago Pérez de Valencia was a dignified gentleman and member of the parliament, who made a compilation of earthquakes felt in Popayan City from 1785 to 1841 . This work is the oldest site catalogue in Colombia. The year, month, hour and sometimes the effects and duration of the earthquakes are provided in chronological order. The catalogue by Santiago Pérez was published by Joaquín Acosta in Paris in 1849 (Espinosa, 1997).

José María Caballero was an infantryman of Santa Fe de Bogota in the independence wars of Colombia. In the military campaign, Caballero wrote in his daily personal notes from 1813 to 1819 , within which are found the descriptions of the effects caused by great and small earthquakes in Santa Fe de Bogota. When the war finished in 1819, Caballero continued his diary adding information on previous events in Santa Fe de Bogota among which are the 1743 and 1785 earthquakes that were very destructive. His compilation includes 1600-1819. Earthquakes outside the city of Santa Fe de Bogota are also described, for instance the Honda earthquake in 1805 , located in the region of the middle Magdalena valley in Colombia. This document was published in 1902 (Caballero, 1902).

The first synthesis of Colombian historical seismology was written in 1898 (fig. 1) by Francisco Javier Vergara y Velasco in the journal Anales de Ingeniería de Bogotá (Vergara y Velasco, 1898). Vergara y Velasco was a high-grade of- 
ficer, an academic and distinguished professor, who compiled records from secondary sources such as classical books of national history of Colombia, Venezuela and Ecuador and regional history of Colombia. As a result of this study, a chronological compilation of textual descriptions of earthquakes and volcanic eruptions from 1530 to the end of the 19th century, was obtained. He published the first seismological map of Colom- bia, which includes the epicentres from his catalogue (Vergara y Velasco, 1906a). This document is the base for the study by Ramírez (1975a).

\subsection{The first investigations}

Between 1930 to 1960 research on regional historical seismology were made by different

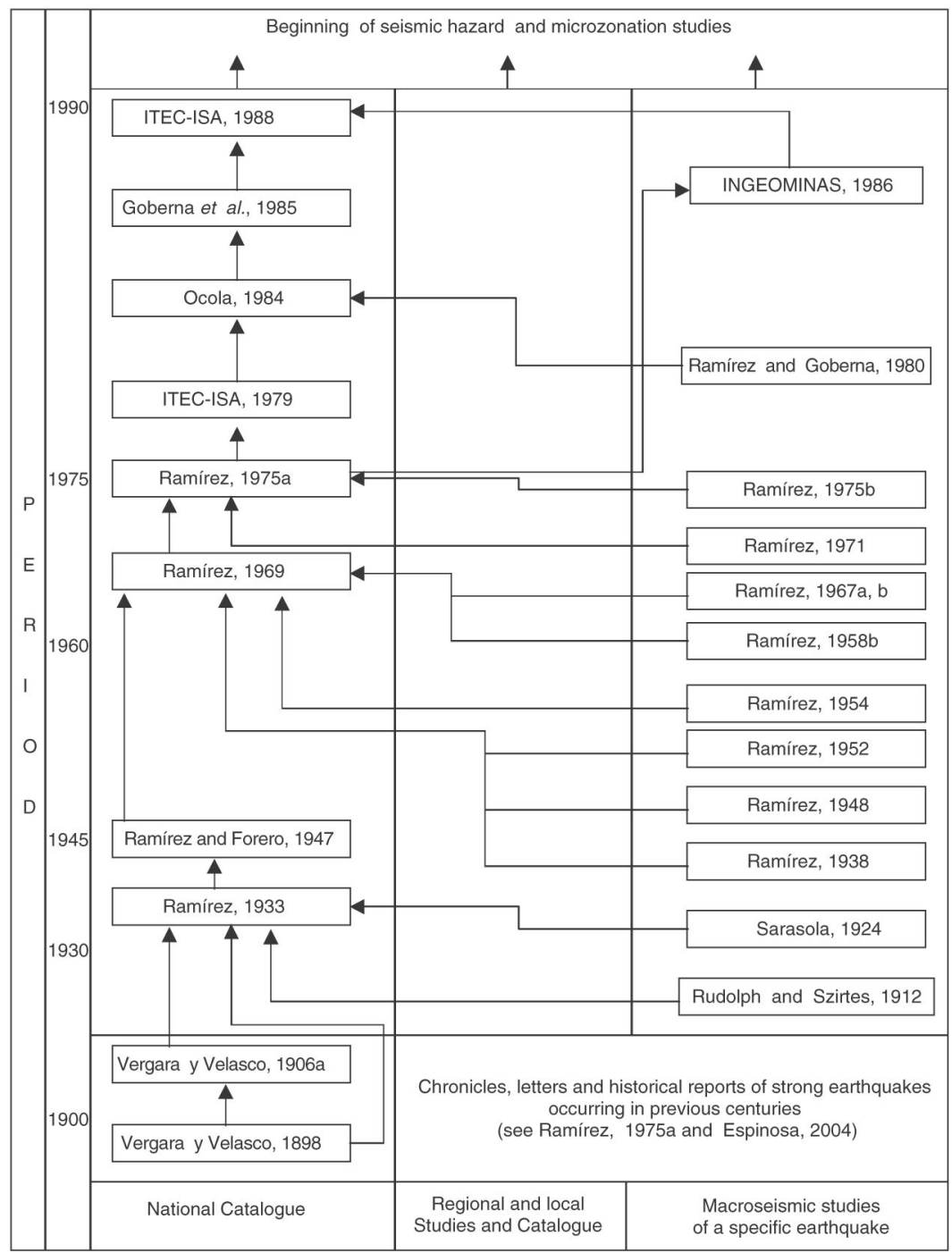

Fig. 1. Family tree of the contribution to the seismic history and specific earthquakes in Colombia before 1990. 
authors from Pasto City, Popayan City and Tunja City among which are the historians Arcesio Aragón, Ramón Correa, the lawyer Ignacio Rodríguez Guerrero and the father Jesús Emilio Ramírez. Aragón published works about history of Popayan and compilations about data of Purace volcano (Aragón, 1926). Correa published a paper about damage caused by great earthquakes in Boyaca region, among which are the $1827,1884,1917,1928,1961$ and 1962 earthquakes (Correa, 1962). Rodríguez Guerrero was the author of historical, geographical and literary books. Rodríguez Guerrero published a compilation about volcanic eruptions in Galeras and Doña Juana Volcano and earthquakes occurred in Colombian southern region from the epoch of the Spanish conquest to his days (Rodríguez Guerrero, 1959, 1961). It is worthwhile to highlight that earthquakes and volcanic eruptions were studied on the same level, in this manner other compilations were made by Muñoz (1925), Friedlaender (1927) and Forero Duran (1933). Ramírez (1975a) and Espinosa $(1997,2004)$ quote these authors.

\subsection{Studies by Ramírez}

The investigation of Colombian historical seismicity started with the studies of Jesús Emilio Ramírez, a geophysicist and Jesuit priest, born in 1904 in the small town of Yolombo not far from Medellin, in northern Colombia and dead in 1981 in Bogota. He was a co-founder in 1941 of the "Instituto Geofisico de los Andes Colombianos» (today «Institu- to Geofísico Universidad Javeriana»). For 38 years, he served as Director of this institution and he is considered one of the pioneers of seismology in Colombia. He produced studies about some individual earthquakes from 1933 to 1981 (fig. 1).

Ramírez published compilations about historical seismicity in Colombia (Ramírez, 1933, 1937, 1947, 1958a, 1968, 1969). The whole study was finished and published in 1975 with the name Historia de los terremotos en Colombia (Ramírez, 1975a). This document is divided into three parts: 1) introduction to seismology, description of Colombian volcanoes and history of volcanic eruptions in Colombia; 2) Colombian historical seismicity; 3) description of the seismicity and seismotectonic map of Colombia and compilation of the first Colombian seismicity catalogue.

The systematic compilation of historical sources made by Ramírez supplied records for 250 earthquakes with textual description from 16 th to 20 th century. The first Colombian event described is the 1566 earthquake in the Popayan and Cali region; the historical compilations which quote this event are Arroyo (1907) and Aragón (1941). The last earthquake described is 12 July 1974 in the Juradó region.

The historical references investigated by Ramírez are contemporary sources of information about the earthquake like chronicles, letters, historical books, daily newspapers, scientific articles, historical compilations of catalogues and individual earthquakes, personal communications, records of public offices, local seismological records and international

Table I. Parametric catalogues in Colombia.

\begin{tabular}{cccccccc}
\hline \hline Author & Period & \multicolumn{6}{c}{ Number of earthquakes included/Century } \\
\cline { 3 - 7 } & & 16 th & 17 th & 18 th & 19 th & 20 th & Total \\
\hline Ramírez (1975a) & $1566-1974$ & 2 & 8 & 23 & 187 & 1036 & 1256 \\
CERESIS (1985) & $1566-1995$ & 3 & 6 & 31 & 220 & 10828 & 11088 \\
$\begin{array}{c}\text { INGEOMINAS (1998) } \\
m_{b} \geq 4.0\end{array}$ & $1541-1998$ & 5 & 22 & 53 & 240 & 4807 & 5127 \\
\hline
\end{tabular}


seismological summary. Some of these sources give a relatively good description of damage, others give a highly accurate timing but only report that the earthquake was felt in distant places with no information of damage. Among the historical sources are Acosta (1828), Boussingault (1829, 1833, 1835), anonymous sources as for example «Letras Anuas de la Compañia de Jesús de la Provincia del Nuevo Reino de Granada» from 1638 to 1643, historical records of public offices found in the National Archive in Bogota and regional archives as for example the Archivo Central del Cauca in Popayan. Historical compilations are quoted as for example Caballero (1902) and Febres Cordero (1931). In conclusion, the study by Ramírez (1975a) is well documented, it supplies good quality information from primary and secondary historical sources to be interpreted in seismological terms.

\section{Earthquake parametric catalogues}

\subsection{Ramírez catalogue (1566-1974)}

The first historical and instrumental earthquake catalogue of Colombia appeared in Ramírez (1975a). This catalogue includes a total of 1256 events (table I). For each event the earthquake parameters are provided: date, epicentral coordinates and locality, earthquake intensity and depth. For the parameters of location of historical earthquakes, the method followed by Ramírez consisted in locating the epicentre of an earthquake in the places where the effects and damage were the greatest. In the case of damage and effect reports approximately equal in two different localities, the epicentre was located mid-way between them (see for example Ramírez, 1954; Ramírez, 1975b). If the damage and effects were greater in one locality than in the other the epicentre was located at a distance inversely proportional to such effects. For the most recent events the epicentre and depth were defined by instrumental methods (see for example Ramírez, 1967a; Ramírez, 1971).

Epicentres of earthquakes that occurred in bordering countries (Ecuador, Panama, Peru and Venezuela), whose effects were felt in Colombia, are included. For historical events the depths are not given, however in some cases the depth of earthquakes was assumed empirically using the isoseismal map (Ramírez, 1975b). The intensity scale used by Ramírez ranges from I to III and has an approximate correlation with the Modified Mercalli Scale of 1956 (MM56): i) I corresponds to III, IV and V; ii) II corresponds to VI, VII and VIII; iii) III corresponds to IX, X, XI and XII.

\subsection{CERESIS catalogue (1566-1995)}

The catalogue of earthquake parameters for Colombia was compiled by CERESIS (Centro Regional de Sismología para América del Sur) during the project «The Program for the Mitigation

Table II. Number of earthquakes and IDP included in the Colombian intensity database of CERESIS (1566-1981).

\begin{tabular}{ccc}
\hline \hline Century & $\begin{array}{c}\text { Number of } \\
\text { earthquakes included }\end{array}$ & Number of IDP/Century \\
\hline 16 th & 2 & 5 \\
17 th & 5 & 16 \\
18 th & 10 & 61 \\
19 th & 26 & 210 \\
20 th & 145 & 1805 \\
Total & 188 & 2097 \\
\hline
\end{tabular}


Armando Espinosa Baquero, Augusto Antonio Gómez Capera and Elkin de Jesús Salcedo Hurtado

\begin{tabular}{|c|c|c|c|c|c|c|c|c|}
\hline HYP & $\mathrm{CO} 00005$ & 1566.00 .00 24:00:00 & 3.000 & -76.500 & & $5.0 \mathrm{M}_{\mathrm{s}}$ & $7 \mathrm{M}$ & 2 \\
\hline $\mathrm{CO}$ & CALI & & 3.45 & -76.53 & 995 & & \multicolumn{2}{|c|}{7 M TPRG 801} \\
\hline $\mathrm{CO}$ & POPAYAN & & 2.45 & -76.62 & 1738 & & \multicolumn{2}{|c|}{$7 \mathrm{M}$ TPRG } \\
\hline HYP & $\mathrm{CO} 00010$ & 1595.03.12 16:00:00 & 4.500 & -75.400 & & $4.0 \mathrm{M}_{\mathrm{s}}$ & $7 \mathrm{M}$ & 3 \\
\hline $\mathrm{CO}$ & \multicolumn{2}{|c|}{ VOLCAN RUIZ } & 4.55 & -75.46 & 5300 & & \multicolumn{2}{|c|}{7 M TPRG 801} \\
\hline $\mathrm{CO}$ & \multicolumn{2}{|c|}{ MARIQUITA } & 5.20 & -74.90 & 495 & & \multicolumn{2}{|c|}{$4 \mathrm{M}$ TPRG } \\
\hline $\mathrm{CO}$ & \multicolumn{2}{|l|}{ HONDA } & 5.20 & -74.93 & 225 & & \multicolumn{2}{|c|}{$4 \mathrm{M}$ TPRG } \\
\hline
\end{tabular}

Fig. 2. Example of CERESIS database format (CERESIS, 1985).

of Earthquake Effects in the Andean Region» (known as project SISRA, CERESIS, 1985, available through http://www.ceresis.org). The catalogue has been compiled using macroseismic and instrumental data related to earthquakes from 1566 to 19 January 1995 . The CERESIS catalogue contains events without a lower limit of magnitude (table I). The main focal parameters are listed (CERESIS, 2003). The compilation of the catalogue was divided in two parts. One was the historical catalogue, where the main bibliographical source was Ramírez (1975a). The second was the instrumental one beginning after 1900 (Goberna et al., 1985).

For the parameters of location of historical earthquakes, the method used is that described in the Ramirez catalogue (Ramírez, 1975a). The evaluation of epicentral intensities used the Modified Mercalli Scale of 1956. For historical events the depths are not given. The magnitude, for historical earthquakes, is based on the formula of Gutenberg and Richter for shallow earthquakes of California: $M=1+2 / 3 \quad I_{0}$ or on the tables of equivalence which have been calculated from this formula (Richter, 1958; Bath, 1967).

The instrumental catalogue was compiled using data from international sources and from local instrumental networks.

\subsection{The Colombian earthquake catalogue (1566-1998)}

The earthquake catalogue for Colombia is a parametric hypocentre catalogue which has been compiled, updated and homogenised in magnitude $M_{s}$ by INGEOMINAS (Colombian Geological Survey) (INGEOMINAS, 1993, 1995a, 1995b, 1997, 1998, 1999a and 2002) using historical and instrumental data, available through http://bases4d.ingeominas.gov.co:10084/. The Colombia earthquake catalogue covers a time period from 1566 to June of 1998 (table I).

For each event there is a line providing the main focal parameters. Quality factors for time, epicentre, depth, and magnitude have been assigned for most of the events. The bibliographic sources are given. The lower magnitude cutoff has been set to $4.0 m_{b}\left(M_{s} \geq 2.4\right)$. The catalogue includes aftershocks. A description of the hypocentre catalogue format can be found in INGEOMINAS (1995b).

The historical sources compiled are secondary, i.e. catalogues from Ramírez (1975a), CERESIS (1985), ITEC-ISA (1988), OSSO (1996), ISC and NEIC, and Catalogue of Colombian National Seismological Network (INGEOMINAS, 2002).

\subsection{Intensity database: CERESIS (1566-1981)}

The CERESIS intensity database for Colombia (CERESIS, 1985, available through http://www.ceresis.org) contains 2097 Intensity Data Points (IDP) related to 188 events from 1566 to 1981 (table II) (Gómez et al., 2002). The proposed epicentre and macroseismic parameters come either from the critical analysis of the different historical sources or from spe- 
cific studies. The main bibliographical sources are Ramírez (1975a) and the Archive of the Instituto Geofísico de los Andes (Goberna et al., 1985).

The format of the CERESIS intensity database (fig. 2) has two types of record. For each event there is a first line providing the parameters (epicentral coordinates, epicentral or maximum intensity, magnitude, depth, number of related IDP - although not always reported) of an earthquake; in the following lines, the IDP related to the earthquakes are listed. All intensities are given using either the MM 56 or MSK (Medvedev-Sponheuer-Karnik) macroseismic scale. The investigator who assigned the intensity value is identified as «interpreter» (TPRG in fig. 2). The references are given with a code (801 in fig. 2). References given in the CERESIS database do not allow one to distinguish which event and/or data point is supported by which source.

A description of the catalogue format is given in Goberna (1985), including the list of the «interpreters» and the references they have used.

Figures 1 and 3 summarize the background of the historical seismic investigations in Colombia, including catalogues, in the periods before and after 1990 respectively.

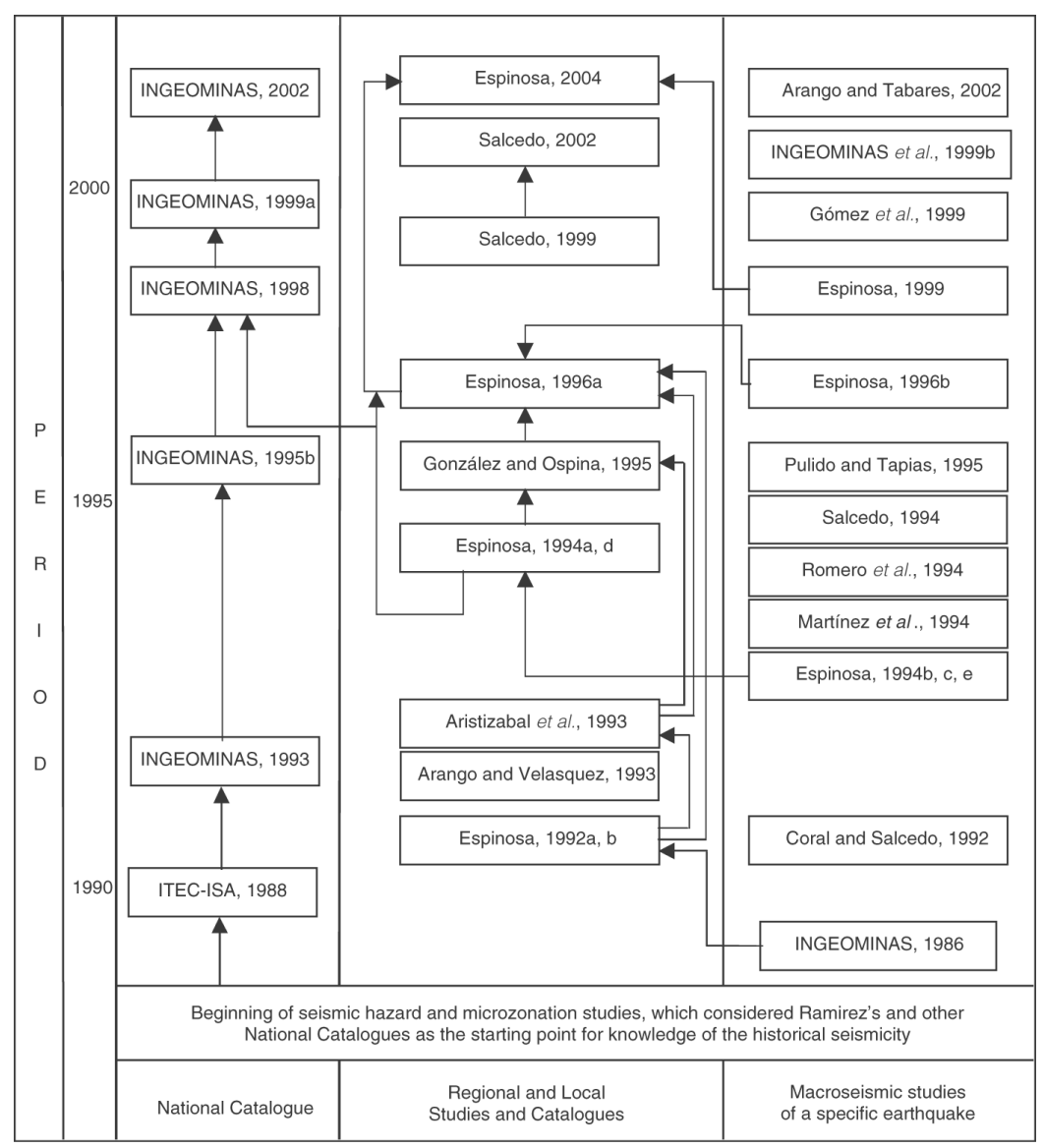

Fig. 3. Family-tree of the seismic history and macroseismic analysis of a specific earthquake as contribution to the seismic hazard and microzonation studies in Colombia after 1990. 


\section{Most recent investigations}

\subsection{Studies by Espinosa}

During the last 20 years, cities as Popayan, Pereira and Armenia have been affected by great, shallow earthquakes. Regional seismic hazard studies began after of the Popayan earthquake, which occurred on 31 March 1983, and the first national building code was developed and adopted in 1984. In both of these national projects, the role played by his-

Table III. Main seismic hazard projects in Colombia with historical seismicity studies.

\begin{tabular}{|c|c|c|}
\hline \multirow{2}{*}{$\begin{array}{l}\text { Type project, } \\
\text { date and place }\end{array}$} & \multicolumn{2}{|r|}{ Historical seismicity } \\
\hline & Study & Remarks \\
\hline $\begin{array}{l}\text { Regional } \\
1985-1992 \\
\text { Valle del } \\
\text { Cauca }\end{array}$ & $\begin{array}{l}\text { Espinosa } \\
(1992 b, 1996 b)\end{array}$ & $\begin{array}{l}\text { Intensive and extensive research of regional historical sources. } \\
\text { Analysis of historical sources. } \\
\text { Regional catalogue. } \\
\text { Analysis of seismogenic sources. } \\
\text { Intensity map for main events. } \\
\text { Example of historical earthquakes studied: } 1766 \text {. }\end{array}$ \\
\hline $\begin{array}{l}\text { Microzonation } \\
\text { 1988-1992 } \\
\text { Popayán }\end{array}$ & $\begin{array}{l}\text { Espinosa } \\
(1992 a, 1994 f)\end{array}$ & $\begin{array}{l}\text { Intensive and extensive research of local historical sources. } \\
\text { Study of } 1983 \text { Popayan earthquake. } \\
\text { Analysis of historical sources. } \\
\text { Analysis of regional seismicity. } \\
\text { Local effects. } \\
\text { Intensity map. } \\
\text { Analysis of local seismogenic sources. } \\
\text { Example of historical earthquakes studied: } 1736,1751,1817 \text {, } \\
1878,1885,1906,1936 \text {. }\end{array}$ \\
\hline $\begin{array}{l}\text { Regional and } \\
\text { Volcanic Hazard } \\
1989 \\
\text { Manizales }\end{array}$ & $\begin{array}{l}\text { Jaramillo and } \\
\text { Arango (1994) }\end{array}$ & $\begin{array}{l}\text { Intensive research of regional historical sources. } \\
\text { Analysis of sources. }\end{array}$ \\
\hline $\begin{array}{l}\text { Regional } \\
1994 \\
\text { Medellín }\end{array}$ & $\begin{array}{l}\text { Arango and } \\
\text { Velasquez (1993) }\end{array}$ & $\begin{array}{l}\text { Intensive research of local historical sources. } \\
\text { Descriptive site compilation. }\end{array}$ \\
\hline $\begin{array}{l}\text { Microzonation } \\
\text { 1993-1995 } \\
\text { Bogotá }\end{array}$ & $\begin{array}{l}\text { Espinosa } \\
(1994 \mathrm{a}, 1994 \mathrm{~b} \\
1994 \mathrm{c}, 1994 \mathrm{~d} \\
1994 \mathrm{e})\end{array}$ & $\begin{array}{l}\text { Intensive and extensive research of local historical sources. } \\
\text { Analysis of historical sources. } \\
\text { Local effects. } \\
\text { Isoseismal intensity maps for main events. } \\
\text { Example of historical earthquakes studied: } 1805 \text { with } I_{\max }=9 \text {; } \\
1785,1827,1917 \text { with } I_{0}=8 \text {; and } 1743,1826,1923 \text { and } 1967 \\
\text { with } I_{0}=7 \text {. } \\
\text { New events: } 1616,1644 \text {. } \\
\text { False quake as: } 1687 \text { in Santa Fe de Bogotá. }\end{array}$ \\
\hline $\begin{array}{l}\text { Regional } \\
1996 \\
\text { Pereira }\end{array}$ & Espinosa (1996a) & $\begin{array}{l}\text { Intensive and extensive research of regional historical sources. } \\
\text { Analysis of historical sources. } \\
\text { Isoseismal intensity maps for main events. } \\
\text { Historical and recent earthquakes as: 1938, 1961, 1962, 1979, } \\
\text { 1991, } 1995 \text {. }\end{array}$ \\
\hline $\begin{array}{l}\text { Microzonation } \\
1997 \\
\text { Bucaramanga }\end{array}$ & Salcedo (2002) & $\begin{array}{l}\text { Intensive research of local historical sources. } \\
\text { Analysis of historical sources. } \\
\text { Descriptive and parametric site catalogue. }\end{array}$ \\
\hline
\end{tabular}


torical seismology turned out to be very important.

Espinosa, using primary and secondary historical sources, studied historical regional seismicity in the frame of seismic hazard projects (fig. 3 and table III). These historical sources have been consulted in national, regional and local archives and libraries of historical cities as Popayan, Pasto, Cali, Buga and Bogota, including the Archivo General de la Nación.

The studies by Espinosa, which include historical and seismological analysis of local and regional seismicity, are considered intensive and extensive (Espinosa, 2004) and will be available through http://www.accefyn.org.co/

\subsection{Main problems in historical research}

As in many other countries, the main problems encountered in historical studies in Colombia regard: manuscript reading due to the physical deterioration documents or to the grammatical and calligraphic language evolution, change of place-name, etc. Moreover, in Colombia, the completeness and reliability of historical earthquake documents depend on many elements, such as population density and socio-cultural background in the different regions in the country. As a consequence, the distribution of historical earthquake documents is not balanced. Most of them are concentrated in the main historical cities, such as Bogota, Popayan, Pasto and Tunja.

Another problem is the presence of false quakes included in primary historical sources. For example, a flood of the San Cristobal river is proposed to explain the terrible and mysterious roar which terrified the town of Santa Fe de Bogota during the night of Sunday 9 March 1687 which was reported as an earthquake in some texts and catalogues (Espinosa, 1994e).

\subsection{Isoseismal maps}

The «Atlas Macrosísmico de Colombia» by Salcedo Hurtado and Gómez Capera (2000) contains a compilation of 35 isoseismal maps of about the same number earthquakes and covers a time period from 1812 to 1999 . The isoseismals maps are presented in chronological order. Every map contains at least three isoseismals. In this compilation the macroseismic field were selected from the following sources: Ramírez (1948, 1953, 1975a, 1975b), Vall (1950), Fiedler (1961), Woodward-Clyde Consultants (1981), Sarria (1985), Meyer et al. (1986), Coral and Salcedo (1992), Romero et al. (1994), Salcedo (1994), Espinosa (1994d, 1996a), Pulido and Tapias (1995), Gómez Capera et al. (1999). In this atlas, macroseismic parameters from isoseismals are proposed for every earthquake in a database format: macroseismic epicentre, macroseismic focal depth, epicentral distance, epicentral elongation distance, transverse of epicentral elongation distance, direction of elongation, isoseismal area and attenuation coefficient. The macroseismic epicentre was determined as the barycentre of the macroseismic field. The epicentral distances were determined using «equivalent circle» method, by setting them equal to the average radii of equivalent concentric circles having areas equal to that encompassed by the corresponding isoseismals. The attenuation coefficient was determined by the Kövesligethy formula. Different intensity scales were used for the construction of the isoseismal maps: Rossi-Forel scale (RF scale), the Modified Mercalli Scale of 1956 (MM56), the Medvedev, Sponheuer and Karnik scale (MSK), the Mercalli-Cancani-Sieberg scale (MCS) and the European Macroseismic Scale-92 (EMS92). This atlas is available through http://www.ingeominas.gov.co/

\subsection{Site catalogues and others}

The site catalogue of Medellin (Arango and Velasquez, 1993) is a seismic-historical catalogue of Medellin and Antioquia region in Colombia with commentary, it was made in the framework of Medellin seismic hazard study (table III). A chronological relation of effects of 49 earthquakes in the region studied is listed. The historical sources are dated in the time period from 1730 to 1979. The historical sources consulted are: Ramírez (1975a), CERESIS (1985), Woodward-Clyde Consultants reports (e.g., 
1981), local chronicles, national and reports from local newspapers, bulletins, magazines, university theses, regional and local historical books.

The catalogue of the effects of recent earthquakes (Salcedo Hurtado and Gómez Capera, 1998) is a compilation of historical records of 63 earthquakes that occurred in the 19th and 20th century in Colombia, in chronological order. This study is in database format with information on historical source, date, location and descriptions of earthquake effects at single localities. Additionally, there is a parametric catalogue (date, coordinates, site and bibliographic source) on 63 earthquakes studied. The total number of bibliographic sources is 41 among which historical books, magazines, technical reports, studies, reports from national and local newspapers and others available at the archives and libraries in Bogota. The catalogue is available through http://www.ingeominas.gov.co

INGEOMINAS (1999c) compiled a wall map of epicentres of $M_{s} \geq 5.5$ and $I_{\max } \geq$ VII earthquakes from 1566 to 1999. This historical map lists the date, coordinates, locality, magnitude and maximum intensity of the earthquakes. Some inset maps show the isoseismals of great earthquakes that hit Colombia between 1875 and 1999 (Salcedo Hurtado and Gómez Capera, 2000).

The site catalogue of Bucaramanga (Salcedo Hurtado, 2002) is a seismic-historical catalogue with commentary and also a site catalogue of the effects in Bucaramanga city and metropolitan area from 1644 to 1997 . The Bucaramanga site catalogue has hypocentral parameters of 69 earthquakes (date, epicentral coordinates, focal depth, magnitude, epicentral intensity and quality). This study was made in the framework of the Bucaramanga seismic microzonation project (table III). The main historical sources consulted are Ramírez (1969, 1975a,b) and reports from local newspapers available at the archives and libraries in Bucaramanga.

Relationships between intensity, focal depth and epicentral distance for earthquakes in Colombia have been recently investigated. The isoseismal maps for 34 earthquakes in different parts of Colombia were analysed to study the focal depth (Gómez Capera and Salcedo Hurtado, 2000) and the attenuation of intensities with distance (Gómez Capera and Salcedo Hurtado, 2002). These estimates are based upon the Blake-Shebalin and Köveslighety models.

\section{Conclusions}

The historical seismicity of Colombia is not documented before the Spanish arrival in the 16 th century. Descriptive compilations and parametric catalogues are available covering the time period between 16th and 20th century.

The main studies on historical seismicity of Colombia can be grouped in two categories. The first comprises the work by Ramirez and all subsequent studies based on this compilation. Ramirez published a descriptive compilation and parametric catalogue of the seismicity occurred between 1566 and 1974, which identifies the most important destructive events through primary and secondary sources found in National and regional archives and libraries of Colombia. This compilation and catalogue is a very important guide for the knowledge of the seismic history of Colombia, since it has been intensively used by CERESIS and INGEOMINAS to compile the most recent parametric catalogue of Colombia.

In the second group are included the studies by Espinosa, in the framework of seismic hazard projects. Espinosa found new historical sources and earthquake records that he was able to locate in time and space.

Despite the important contributions of Espinosa's work, which partially supplement Ramírez, the seismic catalogues in Colombia cannot be considered complete. According to Ambraseys et al. (1983), in a general way the data contained in seismological catalogues need a meticulous revision and reinterpretation. For the Colombian catalogues, this has not been done for the entire period corresponding to the historical seismicity.

The studies of historical seismicity have been carried out in an inhomogeneous way, benefiting the needs of the main cities or of the more developed regions, which required seismic hazard analysis for microzonation studies, in this framework, compilations, site catalogues and isoseismal maps have been developed by different authors but more efforts are still needed. 
The different historical seismic catalogues done for the Colombian territory have not shown meticulous efforts to calculate seismic parameters such as epicentre and focal depth that might be used reliably for the solution of the problem of the seismic hazard. This is a great task for future research.

\section{Acknowledgements}

Special thanks to Massimiliano Stucchi for inviting us to write this paper. Thanks are extended to Valentina Montaldo for help in the English translation and Mario Locati for figures editing.

\section{REFERENCES}

AcostA, J. (1828): Lettre sur le tremblement de terre de la Colombie, adressée a M. Alex Barbie du Bocage, Bull. Soc. Géogr. (Paris), 12 (60-61), 200-203 (reprinted in Arago's «Oeuvres complètes», Paris 1859).

Ambraseys, N., E. Banda, J. Irving, D. Mallard, C. Melville, T. Morse, R. Muir-Wood, D. Muñoz, L. Serva, D. Shilston, E. Surinach and J. Vogt (1983) Notes on historical seismicity, Bull. Seismol. Soc. Am. 73 (6), 1917-1920.

Aragón, A. (1926): El Puracé y sus Leyendas. Mundo al Día (Julio, Bogota), 14-26.

Aragón, A. (1941): Fastos Payaneses, 1536-1936 (Imprenta Nacional, Bogota), vol. 2, pp. 279.

ARANGO, O.H. and J.H. TABARES (2002): Estudio macrosísmico del terremoto de Armenia-Colombia del 25 de enero de 1999: Modelo de reconstrucción geométrica del foco sísmico, M.Sc. Thesis (Department of Engineering, Valle University, Santiago de Cali), pp. 145.

Arango, L.M. and A. VelásQuEZ (1993): Catálogo históri co sísmico para Medellín, Alcaldía de Medellín/PNUD (Editorial Cadena S.A., Medellín), pp. 93.

AristizÁbal, R.D. J.M. GómEZ and O. PatiÑo (1993): Sismicidad histórica y macrosísmica en el Departamento del Quindío, M.Sc. Thesis (Department of Engineering, Quindío University, Armenia), pp. 304 (quoted by Espinosa, 1996b)

Arroyo, J. (1907): Historia de la Gobernación de Popayán (Imprenta del Departamento, Popayán), pp. 370.

BAтH, M. (1967): Handbook on Earthquake Magnitude Determinations (Seismological Institute, Uppsala, Sweeden), pp. 114

Boussingault, J.B. (1829): Lettre de M. Roulin a l'Academie des Sciences en date du 4 mai 1829, sur les circonstances qui accompagnent les tremblements de terre en Amérique, dans la republique de Vénésuéla, Ann. Chim. Phys. (Paris), 42, 410-415.

Boussingault, J. B. (1833): Analyse de l'Alumine sulfatée du volcan de Pasto, Ann. Chim. Phys. (Paris), 52, 348-351.
Boussingault, J. B. (1835): Sur les tremblements de terre des Andes, Ann. Chim. Phys. (Paris), 58, 81-88.

Caballero, J. M. (1902): Días de la Independencia, Publicado en el Diario (La Patria Boba), Biblioteca de Historia Nacional (Imprenta Nacional, Bogotá), vol. 1, pp. 476.

CARDONA, O.D. (1999): The earthquake of Armenia, Colombia, January 25, 1999, Special Report, Geohazards International, pp. 9.

CERESIS (1985): Colombia, Datos de Hipocentros e Intensidades, in Earthquake Mitigation Program in the Andean Region (Project SISRA), edited by B. AsKEW and S.T. AlgERMisSEN, 4, pp. 269.

CERESIS (2003): Consulta de Hipocentros-Parámetros (on line: http://www.ceresis.org).

Coral, C. and E. DE J. SAlcedo (1992): Evaluación preliminar de daños y mapa de isointensidades en la región Chocó - Antioquia afectada por el terremoto del 18 de octubre de 1992, INGEOMINAS, Report (Bogotá), pp. 20.

CORREA, R. (1962): Temblores que han azotado a Colombia, in Repertorio Boyacense (Academia Boyacense de Historia, Tunja), 48, 223-224, 1389-1392.

ESPINOSA, A. (1992a): Sismicidad histórica y reciente del área de Popayán, in Microzonificación Sismogeotécnica de Popayán, INGEOMINAS-CEE, 2, 7-27.

Espinosa, A. (1992b): Sismicidad Histórica del Valle del Cauca (Proyecto GERSCO, report, Cali), pp. 44.

EspinosA, A. (1994a): Contribuciones al catálogo colombiano de sismicidad histórica, I. Cinco terremotos destructores de la Colonia encontrados en los archivos históricos colombianos, Revista INGEOMINAS (Bogotá), 4, 77-82.

ESPINOSA, A (1994b): Contribuciones al catálogo colombiano de sismicidad histórica, II. El terremoto de Tunjuelito (1644, marzo 16) y sus efectos geotectónicos en la zona epicentral, Revista INGEOMINAS (Bogotá), 4, 83-90.

EsPINOSA, A. (1994c): Contribuciones al catálogo colombiano de sismicidad histórica, III. Un falso ruido de Santafé el 9 de marzo de 1687, Revista INGEOMINAS (Bogotá), 4.

EspinOSA, A. (1994d): Sismicidad histórica de Santafe de Bogotá y su área (1500-1994), in Microzonificación Sísmica de Santa Fe de Bogotá, INGEOMINAS Report, pp. 39.

EsPinOSA, A. (1994e): El ruido de Santafe, el 9 de marzo de 1687, y sus posibles causas, Revista de la Academia Colombiana de Ciencias Exactas Físicas y Naturales, 19, (73), 293-297.

Espinosa, A. (1994f): La Amenaza del Volcán Puracé sobre Popayán y Áreas Vecinas Según Análisis de las Erupciones Históricas (CERG, Universidad de Ginebra, Suiza), pp. 60 (unpublished).

EsPINOSA, A. (1996a): Sismicidad histórica, Informe final, in Proyecto para la mitigación del riesgo sísmico de Pereira, Dos Quebradas y Santa Rosa de Cabal, Convenio Carder-Universidad del Quindío.

EsPINOSA, A. (1996b): El terremoto de Buga, el 9 de julio de 1766. Análisis histórico y geotectónico, Revista de la Academia Colombiana de Ciencias Exactas Físicas y Naturales, 20 (77), 247-258.

EsPINOSA, A. (1997): Fuentes y estudios sobre desastres históricos en Colombia, Retrospectiva y Estado Actual, Historia y Desastres en América Latina, edited by V. GARCIA ACOSTA (La Red/CIESAS-ITDG, Lima), 2, 289-315. 
EsPINOSA, A. (1999): El terremoto de los Muzos (1646, abril 3) a la luz de un excepcional documento colonial, la relación de don Bartolomé de Mázmela y Poveda, Revista de la Academia Colombiana de Ciencias Exactas Físicas y Naturales, 23, 87, 205-212.

EsPinosa, A. (2004): Historia sísmica de Colombia (Academia Colombiana de Ciencias Exactas, Físicas y Naturales, Universidad del Quindío), CD-ROM.

Febres CoRdERo, T. (1931): El gran terremoto de Cúcuta y Táchira, a 18 de mayo de 1875, Archivo de Historia y Variedades, Caracas, 2, 152-157.

FRIEDLAENDER, E. (1927): Ueber einige Vulkane Columbiens. Zeitschrift für Vulkanologie, Neapoli, Teil 1, Band 10, 159-172, (translated in 1936 as Estudio científico de algunos volcanes del Sur de Colombia, Ilustración Nariñense, Pasto, 5, 59, January, 6-10).

FIEDLER, G. (1961): Areas afectadas por terremotos en Venezuela, Memorias del Tercer Congreso Geológico Venezolano, Caracas, IV, 1789-1814.

Forero DuRAN, L. (1933): Las erupciones del Galeras, Juventud Javeriana, Bogotá, 3 (1), 268-272; 3 (2), 304306; 3 (3), 343-346

Goberna, R., W. Arias, J. Duarte, T. Palencia and T. VARGAS (1985): Catálogo de Terremotos para América del Sur, Colombia, edited by B. AsKew and S.T. ALGERMISSEN (CERESIS, Lima), IV.

GobernA, J.R. (1985): Informe Nacional de Colombia, en Catálogo de Terremotos para America del Sur, CERESIS, Descripción del Catálogo e Informes Nacionales, Programa para la mitigación de los efectos de los terremotos en la región andina, in Earthquake Mitigation Program in the Andean Region (Project SISRA), edited by B. Askew and S.T. Algermissen, 1, pp. 191.

Gómez Capera, A.A. and Red Nacional De AceleroGRAFOS (1999): Mapa de intensidades del terremoto de enero 25 de 1999 (Preliminar), INGEOMINAS in Mapa de Grandes Sismos en Colombia, 1566-1999, Bogotá.

Gómez Capera, A.A. and E. De J. Salcedo Hurtado (2000): Determinación de la profundidad focal de algunos sismos ocurridos en Colombia, a partir de datos macrosismicos, Revista de la Red Sismológica del Eje Cafetero Viejo Caldas y Tolima, Manizales, 5, 12-16.

Gómez CAPERA, A.A., I. Leschiutta and E. Migliorini (2002): A preliminary attempt of determining the parameters of earthquake sources in South America using intensity data points from the CERESIS database, in Proc. VII International Congress of Earth Science, Santiago (Chile), 21-25 October 2002, pp. 16 (accepted).

Gómez Capera, A.A. and E. De J. Salcedo Hurtado (2002): Leyes de atenuación de la intensidad macrosísmica en Colombia, Revista Geofísica Colombiana, 6, 53-61.

GonZalez, R. D. and J. N. Ospina (1995): Macrosísmica y sismicidad histórica en el Departamento del Tolima, M.Sc. Thesis (Department of Engineering, Quindío University, Armenia), pp. 194 (quoted by Espinosa, 1996b).

INGeominas (1986): El Sismo de Popayán del 31 de Marzo de 1983, Bogotá, pp. 320.

Ingeominas (1993): Proyecto de Sismotectónica del Territorio Colombiano, Actualización de la Información Sísmica de Colombia.

INGEOMINAS (1995a): Estudios sismológicos, Subproyecto
No. 5, Sismicidad Instrumental, en Proyecto Microzonificación Sísmica de Santa Fe de Bogotá, Report, pp. 41.

INGEOMINAS (1995b): Revisión y actualización del Catálogo Sísmico Colombiano, Proyecto de Microzonificación Sísmica de Santa Fe de Bogotá, pp. 10.

INGEOMINAS (1997): Informe de Homogenización del Catálogo CERESIS-91 para el Proyecto Piloto-CEE, Bogotá, pp. 12.

INGEOMINAS (1998): Actualización y homogeneización del Catálogo Sísmico Colombiano 1995-1998 (informe preliminar), Proyecto Estudio de Amenaza Sísmica de Colombia, edited by C. Alvarado, Bogotá, pp. 6.

INGEOMINAS (1999a): Actualización Catálogo de sismos de Colombia para estudios de amenaza sísmica 15661998, Datos de Hipocentros e Intensidades, Proyecto Estudio de la Amenaza Sísmica de Colombia, edited by C. Alvarado (Bogotá), pp. 16.

INGEOMINAS and UNIVERSIDAD DEL Quindío (1999b): Informe del terremoto del Quindío (Enero 25 de 1999), Informe Técnico-Científico II, Zonificación Sismogeotécnica para la Reconstrucción de Armenia.

INGEOMINAS (1999c): Mapa de grandes sismos en Colombia, 1566-1999, escala 1:2 000 000, SubDirección de Geofísica, Proyecto de Sismotectónica del Territorio Colombiano, Bogotá.

INGEOMINAS (2002): Base de Datos de sismicidad de Colombia, Red Sismológica Nacional y Red Nacional de Acelerógrafos de Colombia, Bogotá.

ITEC-ISA (1979): Actualización de la información sísmica de Colombia, (Ing. Técnica y Científica Ltda. Bogotá), pp. 200 (unpublished).

ITEC-ISA (1988): Actualización de la Información Sísmica de Colombia (ITEC Ltda, Ingenieros Consultores, Bogotá), pp. 26 (unpublished).

JARAMILLO, J.E. and W. ARANGO (1994): Sismicidad histórica de Manizales, M.Sc. Thesis (Department of Engineering, National University, Manizales).

Martínez, J.M., E. Parra, G. París, C.A. Forero, M. BusTAMANTE, O.D. CARDONA and J.D. JaRAMILlo (1994): Los Sismos del Atrato Medio 17 y 18 de Octubre de 1992 Noroccidente de Colombia, Revista INGEOMINAS, (Bogotá), 4.

Meyer, H., J. Duarte and A. Paraffan (1986): El Sismo de Popayán del 31 de marzo de 1983 (INGEOMINAS, Bogotá), 119-147.

Montessus De Ballore, F. (1884): Temblores y Erupciones Volcanicas de Centro América, San Salvador.

MuÑoz, H. (1925): Carta a La Primavera, Ilustración Nariñense, Pasto, 5, 8.

Ocola, L. (1984): Catálogos sísmicos, República de Colombia, Proyecto de Sismicidad Andina - SISAN, II (OEA-CERESIS, Lima), pp. 200.

Osso (Observatorio Sismologico del Suroccidente Colombiano de la Universidad del Valle) (1996): Catálogo Sísmico del Suroccidente Colombiano, 1987-1996.

PARIs, G., M. Machette, R. DART and K. Haller (2000): Map and database of quaternary faults and folds in Colombia and offshore regions, U.S. Geological Survey Open-File Rep. 00-0284, pp. 61.

Pulido, N. and M. TAPIAS (1995): Aplicación de la Escala Macrosísmica Europea de 1992 en la determinación de las intensidades del sismo de Tauramena (Casanare) 
del 19 de Enero de 1995, in Proc. «Seminario de Sismotectónica del Borde Llanero Colombiano», INGEOMINAS, Bogotá, 83-99.

RAMíREZ, J.E. (1933): Earthquake history of Colombia, Bull. Seismol. Soc. Am., 23 (1), 13-22.

RAMÍREZ, J.E. (1937): Recent seismic activity in the departamento de Nariño, Colombia, S.A., August 1935-August 1936, Bull. Seismol. Soc. Am., 27, 211-223.

RAMíREZ, J.E. (1938): Algunas notas sobre el terremoto colombiano del 4 de Febrero de 1938, Revista Javeriana, Bogotá, IX (41), 340-344.

RAmíREZ, J.E. (1948): The Pasto, Colombia, earthquake of July 14, 1947, Bull. Seismol. Soc. Am., 38 (4), 247-256.

RAmíREZ, J.E. (1952): The Colombian earthquake of February 14, 1952, Earthquake Notes, Washington, 23 (1), 45.

RAMírez, J.E. (1954): El Terremoto de Arboledas, Cucutilla y Salazar de las Palmas, 8 de julio, 1950 (Instituto Panamericano de Geografía e Historia, Buenos Aires), 172, pp. 63.

RAMíREZ, J.E. (1958a): Introducción a la historia de los terremotos colombianos, Revista Eclesíastica Javeriana, 6, 1-17.

RAmíReZ, J.E. (1958b): Los terremotos de Enero y Febrero de 1958 en la costa del Pacífico de Ecuador y Colombia, Publicación del Instituto Geofísico de los Andes Colombianos, Serie A, Sismología (Bogotá), 14.

RAmíreZ, J.E. (1967a): El Macrosismo del Huila, Revista Javeriana, Bogotá, 67 (333), 323-333.

RamíreZ, J.E. and J.H. STREeT (1967b): Colombia (Terremoto) February 9, 1967, (Seismological Notes), Bull. Seismol. Soc. Am. 57 (4), 825-826.

RAMíReZ, J.E. (1968): Historia de los terremotos en Colombia, Bol. Bibliog. (IPGH), Geof. Ocen. Am., 14 (1965/1967), 1-146.

RAmíREZ, J.E. (1969): Historia de los Terremotos en Colombia (Editorial Argra, Bogotá), pp. 218.

RAmíreZ, J.E. (1971): El Terremoto de Bahía Solano del 26 de Septiembre de 1970 (Informes técnicos, Ministerio de Agricultura, Corporación Nacional para el Desarrollo del Chocó), 5-52.

RAmíreZ, J.E. (1975a): Historia de Los Terremotos en Colombia (Instituto Geográfico Agustín Codazzi, Bogotá), 2nd edition, pp. 250 .

RAmíreZ, J.E. (1975b): El Terremoto de Cúcuta Cien Años Después. 18 de Mayo de 1875-18 de Mayo de 1975 , Publicación del Instituto Geofísico de los Andes Colombianos, Universidad Javeriana (Editora Desarrollo S.A., Bogotá), pp. 63.

RAMíREZ, J.E and J. GobERNA (1980): Terremotos Colombianos Noviembre 23 y Diciembre 12 de 1979, Publicación del Instituto Geofísico de los Andes Colombianos, Universidad Javeriana, Serie A, Sismología, (Bogotá), 45, pp. 95.

RAmíreZ, J.E. and L. Forero DurÁn (1947): Mapa sísmico y tectónico de Colombia, Banco de la República, Sec. Inv. Económicos, Boletín Gráfico, Bogotá, 7.

Richter, C. F. (1958): Elementary Seismology, W.H. Freeman and Company, Inc., pp. 768.

RodríGuEZ GuERRERO, I. (1959): Estudios Geográfios sobre el Departamento de Nariño, Imprenta del Departamento, Pasto.

RodríGUEZ GUERRERo, I. (1961): Geografía Económica de
Nariño, 1, Geografía Física, (Editorial Sur Colombiana, Pasto).

Romero J., J. M. Martínez, G. Avila and J. Escallón (1994): El sismo del 21 de Julio de 1993, Puerto Rondón, Llanos Orientales de Colombia, Revista INGEOMINAS, 4, 15-34.

Rudolph, E. and S. SzIRTES (1912): Das Kolumbianische Erdeben am 31. Januar 1906, Gerlands Beiträge zur Geophysik, Band 11, I, II, 132-199; III, 207-275.

Salcedo Hurtado, E. De J. (1994): Mapa de isosistas del terremoto de Páez de Junio 6 de 1994, INGEOMINAS Report, Bogotá, pp. 9.

Salcedo Hurtado, E. De J. (1999): Estudio de la sismicidad histórica en la región de Bucaramanga (Colombia), Revista de la Academia Colombiana de Ciencias Exactas, Físicas y Naturales, 23 (87), 233-248.

Salcedo Hurtado, E. De J. (2002): Sismicidad Histórica y Análisis Macrosísmico de Bucaramanga, Boletín Geológico, IngeOminas, Bogotá, 40 (1), pp. 180.

Salcedo Hurtado, E. De J. and A.A. Gómez Capera (1998): Estudio macrosísmico, Sismicidad Histórica y Reciente, Base de Datos; Reporte Interno, Proyecto de Sismotectónica del Territorio Colombiano, INGEOMINAS, Bogotá, pp. 134.

Salcedo Hurtado, E. De J. and A.A. Gómez CAPERA (2000): Atlas Macrosísmico de Colombia, Proyecto de Sismotectónica del Territorio Colombiano, INGEOMINAS, Report, Bogotá, pp. 108.

SARAsola, S. (1924): Los terremotos de Colombia en el mes de diciembre de 1923, Notas Geofísicas y Meteorológicas, Bogotá, Apéndice No. 1, 80-84 (Reproducido en 1924 en el apéndice a Noticias del Nuevo Observatorio con algunos datos sobre la Climatología y el Magnetismo de Colombia).

SARASOLA, S. (1937): Origen de los actuales terremotos. Sistemas aconsejables para construcciones asísmicas, $J u$ ventud Javeriana, Pasto, Año 4, n. 1 January, 128-131.

SARria, A. (1985): Sismos y Riesgo sísmico en Colombia, in Simposio sobre el Peligro y Riesgo Sísmico y Volcánico en América del Sur, CERESIS, 14, 330-371.

VAll, M. (1950): Mapa isosísmico del terremoto de El Tocuyo (3 de Agosto de 1950), Ministerio de Fomento, Instituto Nacional de Minería y Geología, Caracas, (quoted in Terremotos destructores del Caribe 15021900, 1994, edited by J. GRASES, UNESCO).

Vargas Jurado, L. (1902): Tiempos coloniales La Patria Boba, Biblioteca de Historia Nacional, I (Imprenta Nacional, Bogotá).

VergaRA Y Velasco, F. J. (1898): Los terremotos en Colombia, Anales de Ingeniería, Bogotá, X (118), 186-192.

Vergara y Velasco, F. J. (1906a): Atlas Completo de Geografía Colombiana, Carta Sismológica de Colombia 5-8, Geografía Chibcha 1-4, El Caquetá 1-2, Centros de Población 1-2, Los Origenes de Colombia 1-2 (Imprenta Eléctrica, Bogotá).

Vergara y Velasco, F. J. (1906b): Carta Sismológica de Colombia, Anales de Ingeniería, Bogotá; 14 (161), 6-14.

Woodward-Clyde Consultants (1981): Preliminary study of Geomorphology and Quaternary stratigraphy, Ituango project, Colombia, Report to Integral Ltda., (quoted in W. PAGE, 1986, Geología sísmica y sismicidad del noroeste de Colombia). 